Int. J. Electrochem. Sci., 13 (2018) $9600-9617$

International Journal of

ELECTROCHEMICAL

SCIENCE

www.electrochemsci.org

\title{
Pantoprazole Sodium as a Corrosion Inhibitor for Zinc in Acidic Solutions
}

\author{
M. Saadawy \\ Chemistry Department, Faculty of Science, Alexandria University, Ibrahimia, P.O. box 426, \\ Alexandria 21321 \\ E-mail: marwan.saadawy@yahoo.com
}

doi: $10.20964 / 2018.10 .02$

Received: 26 February 2017 / Accepted: 9 January 2018 / Published: 1 September 2018

Pantoprazole Sodium (PAN) was tested as a corrosion inhibitor for zinc in aqueous solutions of $0.5 \mathrm{M}$ $\mathrm{H}_{2} \mathrm{SO}_{4}, 1 \mathrm{M} \mathrm{HCl}$ and $1 \mathrm{M} \mathrm{HClO}_{4}$ at $30^{\circ} \mathrm{C}$ using absorbance measurement, electrochemical techniques; potentiodynamic polarization and AC-impedance techniques. The results obtained revealed that PAN could inhibit the corrosion of zinc effectively only in $1 \mathrm{M} \mathrm{HClO}_{4}$. The values of binding constants obtained for PAN in $0.5 \mathrm{M} \mathrm{H}_{2} \mathrm{SO}_{4}, 1 \mathrm{M} \mathrm{HCl}$ and $1 \mathrm{M} \mathrm{HClO}_{4}$ solutions for zinc after fitting the data to different adsorption isotherms could be arranged as follows: perchloric acid > hydrochloric acid > sulphuric acid. This order agrees to a great extent with the values of inhibition efficiency calculated from absorbance and different electrochemical techniques.

Keywords: zinc; polarization; absorbance; AC-impedance; acid corrosion; inhibition; pantoprazole.

\section{FULL TEXT}

(C) 2018 The Authors. Published by ESG (www.electrochemsci.org). This article is an open access article distributed under the terms and conditions of the Creative Commons Attribution license (http://creativecommons.org/licenses/by/4.0/). 